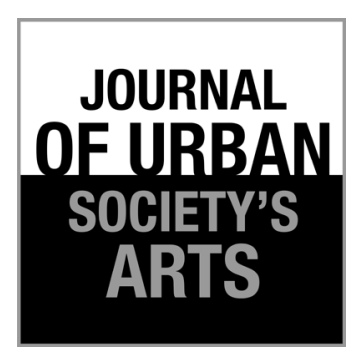

Volume 7 Nomor 2,

October 2020: 74-82

\section{Designing Marine-Park-Inspired Batik Patterns and Their Application on Masks as Pangandaran Tourism Souvenirs during Covid-19 Pandemic}

\section{Husen Hendriyana}

Faculty of Art and Design, Institut Seni Budaya Indonesia Bandung,

Buah Batu Street No. 212, Bandung-40265

Email: husenkriyadesain@gmail.com; HP.: +62818639395

Komarudin Kudya

Craft Study Program, Muhammadiyah University, Bandung

ASM Atamtajani

School of Creative Industries, Product Design Study Program,

Telkom University, Bandung

\begin{abstract}
Pangandaran is known as one of the tourist destinations in West Java Province with its beautiful natural marine charm. The charm of the beauty of Pangandaran beach and its surroundings attracts tourists' attention and reaches 4,044,204 visitors in 2018. Pangandaran has 21 beach tourist destinations. Therefore, souvenirs become one of the aspects that strongly complement tourism in Pangandaran, a tourism souvenir. This study aims to produce innovative products of featured art supporting tourism by raising the iconic potential of natural resources and artisan resources from the local community. This article is one of the results of the applied research in the type of practice-based research focusing on the creative industry of craft art (batik) products that support tourism through eco-design and eco-tourism approaches. In its application, this study uses the design thinking method, with the results in the form of a prototype of mask product for tourism souvenir with marine park pattern application.
\end{abstract}

Keywords: mask; batik pattern; tourism souvenirs; Pangandaran

\begin{abstract}
ABSTRAK
Corak Batik Taman Laut dan Aplikasinya pada Topeng Sebagai Cinderamata Wisata Pangandaran Saat Pandemi Covid-19. Pangandaran dikenal sebagai salah satu destinasi wisata di Provinsi Jawa Barat dengan pesona alam bahari yang indah. Pesona keindahan pantai Pangandaran dan sekitarnya menarik perhatian wisatawan dan mencapai 4.044.204 pengunjung pada 2018. Pangandaran memiliki 21 destinasi wisata pantai. Oleh karena itu, cinderamata menjadi salah satu aspek yang sangat melengkapi pariwisata di Pangandaran yaitu cinderamata pariwisata. Penelitian ini bertujuan untuk menghasilkan produk-produk inovatif seni unggulan pendukung pariwisata dengan mengangkat potensi ikonik sumberdaya alam dan sumberdaya pengrajin dari masyarakat sekitar. Artikel ini merupakan salah satu hasil penelitian terapan pada jenis penelitian berbasis praktik yang berfokus pada industri kreatif produk seni kriya (batik) yang mendukung pariwisata melalui pendekatan ekodesain dan ekowisata. Dalam aplikasinya, penelitian ini menggunakan metode design thinking, dengan hasil berupa prototipe produk topeng cinderamata pariwisata dengan penerapan pola taman laut.
\end{abstract}

Kata kunci: topeng; pola batik; cinderamata pariwisata; Pangandaran 


\section{Introduction}

Since March 20, 2020, people's activities in Pangandaran Regency have decreased due to the release of the West Java government decree regarding the large-scale social restriction and following the health protocol of Covid-19. The closing of tourist spots in the Pangandaran Regency has had an impact on the number of tourists visiting Pangandaran. This also has had an impact as it has crippled the supporting economy of tourism, such as SMI/SME/MSME (IKM/ UKM/UMKM) in Pangandaran that produce souvenir products. Therefore, strategic steps are needed in alleviating the downturn in the MSME sector (Ramadhan, 2020). There are many efforts in coaching, training, and mentoring SME/MSME actors that are carried out in several places (Nury Ariani Wulansari et al., 2015) (Ridwan et al., 2014) (Ananda \& Susilowati, 2019)(Tri U, 2013) (Dipta, 2008), and specifically for SMI/SME producing batik-related products, there is a need to evaluate the adjustments to the products in the Covid-19 pandemic (Pratiwi \& Kartikasari, 2018). During the Covid-19 outbreak, the main aspect that needs to be done is to develop the creativity of SMI actors (Sucahyawati, 2019). The creativity of SMI actors who creates t-shirts and other clothes types for tourists should be used to transform these products to other types of products (Suroso Putro et al., 2019), which in this case is batik masks; in other words, this is a diversification of clothing products ( $\mathrm{t}$-shirts and beach clothes) that takes the form of masks with batik patterns. This strategic move must be made due to the condition of the artisans and beach shirts merchants who have suffered during this pandemic while the economy wheel as well as the fulfillment of daily necessities for the families of the artisans and merchants still need to continue. This unfavorable situation demands creativity from for the community, especially from the SMI/SME/ MSME communities that produce $\mathrm{t}$-shirts and other clothes for tourists.

Another reason for the researchers to pay much attention towards the artisans designing and producing tourist souvenir products is that SMI/SME/MSME sector is the most dominant field in supporting the economy of the artisans' communities, the region, and even the country. Based on the data from The Ministry of Cooperatives and SMEs (2018), approximately $97 \%$ of the SME sector in Indonesia had contributed to job creations as shown in Table 1.

In addition, various seminars and workshops on SME/MSME that have continued to be organized emphasize that the SME sector has the most important role in the people's economy development in Indonesia in the sub-sectors of production, management, and entrepreneurial marketing (Sarma, 2020) and (Mukti, 2020).

Many academics and researchers have carried out studies with several types of topics that are focused on issues related to Covid-19 outbreak. The real condition in the field is indeed a real object that must be considered in relation to the handling of various problems. One of the fundamental problems for SME/MSME actors who design and produce t-shirts and other clothing products for tourists is how to revive their business and develop their business strategies to maintain it. One of the assumptions that can be made a hypothesis in designing a product with the similar product type that can support the wheel of the economy so that the daily needs of the artisans and their family can

Table 1. The role of MSME in Indonesia.

\begin{tabular}{|c|c|c|c|c|c|}
\hline & \multicolumn{2}{|c|}{$\begin{array}{c}\text { Business Unit/ } \\
\text { Company }\end{array}$} & \multicolumn{2}{|c|}{$\begin{array}{l}\text { Absorption of } \\
\text { Workforce }\end{array}$} & \multirow{2}{*}{ Number of MSME } \\
\hline & total & $\%$ & total & $\%$ & \\
\hline Micro business & $63,350,222$ & 98.68 & $107,376,540$ & 89.04 & $64,194,057$ units $(99.99 \%)$ \\
\hline Small business & 783,132 & 1.22 & $5,831,256$ & 4.84 & $116,978,631(97 \%)$ \\
\hline Medium business & 60,702 & 0.09 & $3,770,835$ & 3.13 & \\
\hline Big business & 5,550 & 0.01 & $3,619,507$ & 3.00 & $\begin{array}{r}5,550 \text { units }(0.01 \%) \\
3,619.507(3.00 \%)\end{array}$ \\
\hline
\end{tabular}


be fulfilled is an idea of designing and producing face masks. Masks have become a basic need for clothing in a cultural response to the outbreak of the Corona virus (Sunaryo, 2020). Mainly, masks can be worn by communities with an education motivation ('Atiqoh, N Sari \& Sholihah, 2020); these masks do not have to be bought from a store or even from a factory outside the region. Instead, people can be educated to design and produce their own face masks. The iconic potential (Hanfan, 2017) of Pangandaran tourism can also be a source of inspiration for the surface design of Pangandaran batik mask products. The potential skills of local artisans and their home industries, as well as the potentials of Pangandaran as a tourist destination that has a variety of icons such as marine parks, beaches, and natural beauties can be used as an inspiration to design batik patterns for the face masks. These masks can be a flagship souvenir of Pangandaran, and they can come with patterns representing marine parks, fishes, or other marinerelated beauties.

\section{Research Methods}

The focused discussion relates to the output of this practice-led research application, and therefore, the method used is the creative process of design thinking that comprises several aspects and phases such as: empathize (understand and observe), define (Point of View), ideate, prototype, and test (Christian, 2018 and Hendriyana, 2018 : 22-23).

\section{xResult and Discussion}

During the inactivity period of tourism souvenir producers in Pangandaran, the process of making batik masks can be done by involving and empowering housewives and youth groups, as has been done by Ngatini and Sugiyarto (Ngatini et al., 2020); (Sugiyarto, 2020). This effort that is aimed to support the economy during the Covid-19 pandemic through public education to consume and or using local products, through retail selling targeting the producers' own community, is similar to the one conducted by Pakpahan (Pakpahan, 2020).

While educating the community groups to make and wear the Pangandaran marine-parkinspired batik masks to the batik artisans and beach shirt producers, the process of this activity can be described as one of the works of practice-ledresearch craft. Based on the process of creating the work as presented in the above research method, the stages of this practice-led research process can be described with a focus on designing the marinepark-inspired batik patterns and their application on face masks as tourist souvenirs in Pangandaran. The followings are the stages.

1. Empathize is to the first stage aimed to gain empathic understanding for the problem to be solved. At this stage, the researchers recorded and raised the issue and the potentials that exist by identifying various problems affecting the batik artisans and beach $\mathrm{t}$-shirts producers

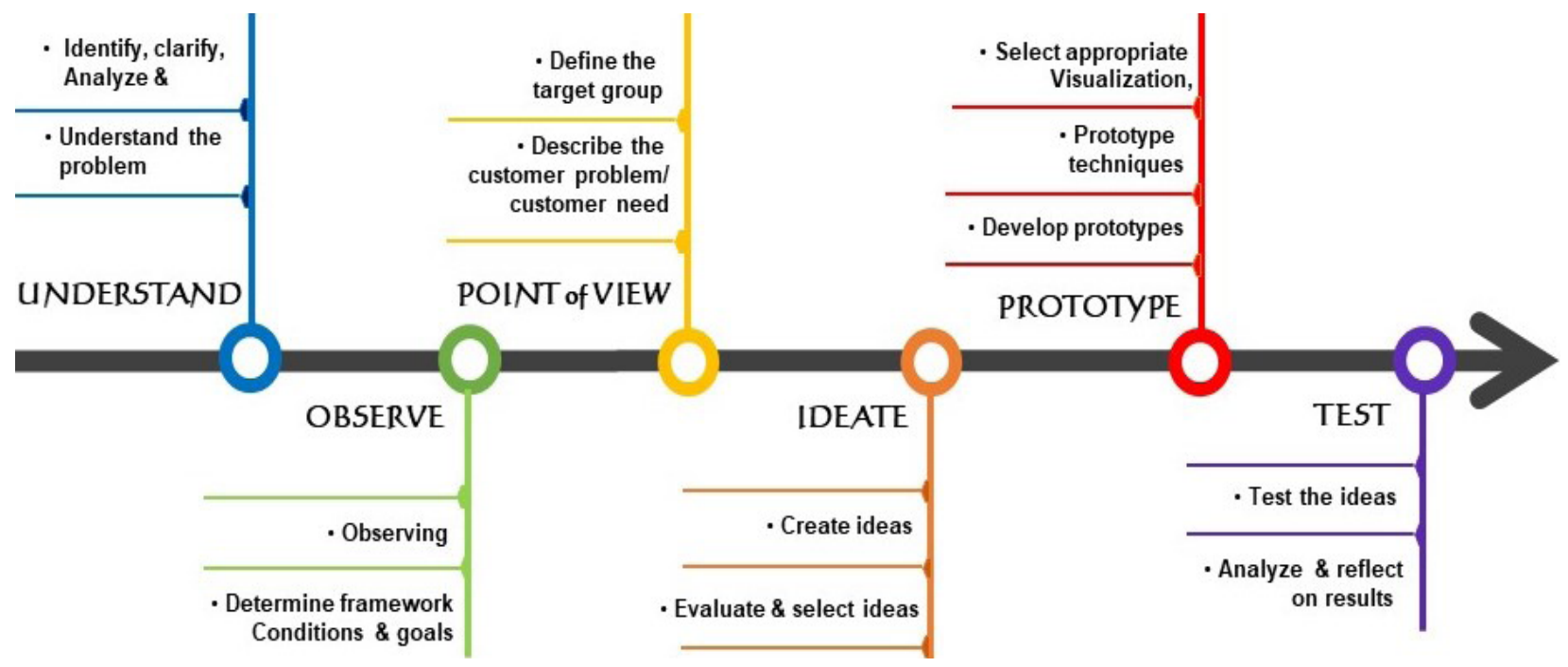

Figure 1. Design Thinking chart. Source: Christian Mueller-Roterberg, 2018. 
their products are the main products of beach souvenirs for tourists. The researchers then studied the users and buyers as well as looking for alternatives for the solutions on the problems obtained through empathy, observation, interviews, literature and typology of the products that are relevant to the needs, situation, and the condition in the Covid-19 pandemic.

At this stage, the researchers gained empathy for the problem from:

a. many batik artisans and beach t-shirts producers that usually sold their products on the tourist spot, Pangandaran. Because of the Covid-19 pandemic, for approximately 6 months (March-August 2020), they were no longer able to sell their products, so that they no longer gained any income meet their daily needs.

b. based on the data obtained from the Department of Tourism and Culture (Disparbud) of Pangandaran, Pangandaran Regency has 21 tourist destinations of beaches lined up from the furthest east to the west end.
1) Majingklak Beach
2) Palatar Agung Beach
3) Pantai Solok Timur Beach
4) Pantai Karapyak Beach
5) Pantai Batu Kasur Beach
6) Pantai Karangnini Beach
7) Lembah Putri Beach
8) Bojong Karekes Beach
9) Timur Pangandaran Beach
10) Pangandaran Beach
11) Karangtirta Beach

12) Batu Hiu Beach

13) Bojong Salawe Beach

14) Batu Karas Beach

15) Batu Nunggul Beach

16) Madasari Beach

17) Legokjawa Beach

18) Muara gata Beach

19) Keusik luhur Beach

20) Pambokongan Beach

21) Ciparanti Beach

These potentials can be used as iconic batik pattern inspirations that can be applied on the masks.

2. Define is the second stage that is a process of identifying the more focused and detailed problems. At this stage, the designers/researchers of this practice-led research discovered and/or sharpened the focus of the problem through a process of in-depth analysis, programming, and problem seeking by conducting or making the following:

a. Analysis of user needs, solutions, and innovations.

At this stage, researchers focused more on the forms of the products that can be made, material studies, the techniques, and sales by considering market opportunities during the Covid-19 pandemic that cover rural and urban communities, young and old people, women and men, artisans and retailers through online media and social media, such as WhatsApp, Instagram, and Facebook.

b. Design framework as a summary and formulation of the results of the initial analysis.

At this stage the researchers decided to
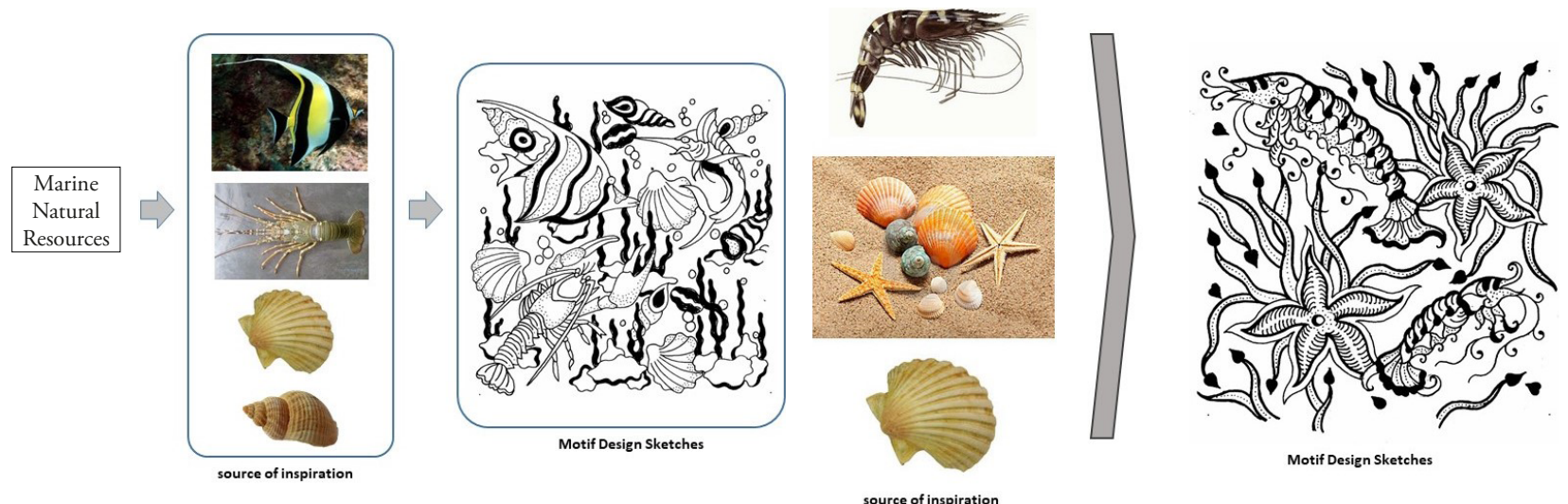

Figure 2. Visualization of ideas and concepts. 
temporarily put aside the products of clothing, such as shirts and beachwear, which have no buyers. In response to the condition caused by the Covid-19 pandemic, at this stage the researcher began to design batik face masks using printing and hand drawing (using canting) technique in certain sections to create the desired patterns and colors.

c. Problem statements and general concepts as work formulations to solve the design problems.

At this stage, the researchers focused on matters related to themes, other issues, object-related issues, the community running the business (production management), and the users' community (market). As it was mentioned earlier, the decision made from raising the issues on the batik artisans and shirt/ beachwear producers was the switching to face mask production. These masks can be used by their own community, and, therefore, they do not have to buy the masks from other regions. At the same time, they are making effort in promoting Pangandaran as a tourist destination through its marine life represented by patterns on the face masks that they design and produce.

3. Ideate is the next stage, in which the designers/ researchers of this practice-led research of were trying to finalize and/or clarify ideas by brainstorming using mind mapping to produce the following:

a. The design concept that can underlie all design implementations.

To obtain a good concept according to the design decisions, at this stage the idea needs to be tested through a comparative study with the quality of the competitors' products and their market. The important thing at this stage is to create an innovation of batik patterns applied to the masks; a similar attempt was done by $\mathrm{Li}$ (Li et al., 2009).

b. Designing a good working drawing

At this stage, the researchers archived design transformation by making a good mind mapping from an abstract image

\section{COLORING PROCESS}

1 Naphthol Solution (measurement per 1 meter fabric) $10 \mathrm{gr}$ Naphthol powder $5 \mathrm{gr}$ Caustic Soda $5 \mathrm{gr}$ TRO $10 \mathrm{gr}=1$ tablespoon $5 \mathrm{gr}=1$ teaspoon

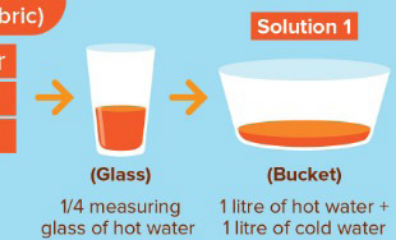

glass of hot water 1 litre of hot water

\section{Brine Solution}

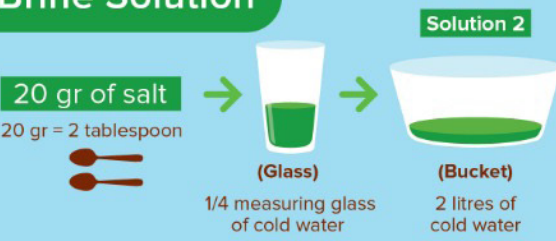

\section{THE COLORING STEPS}
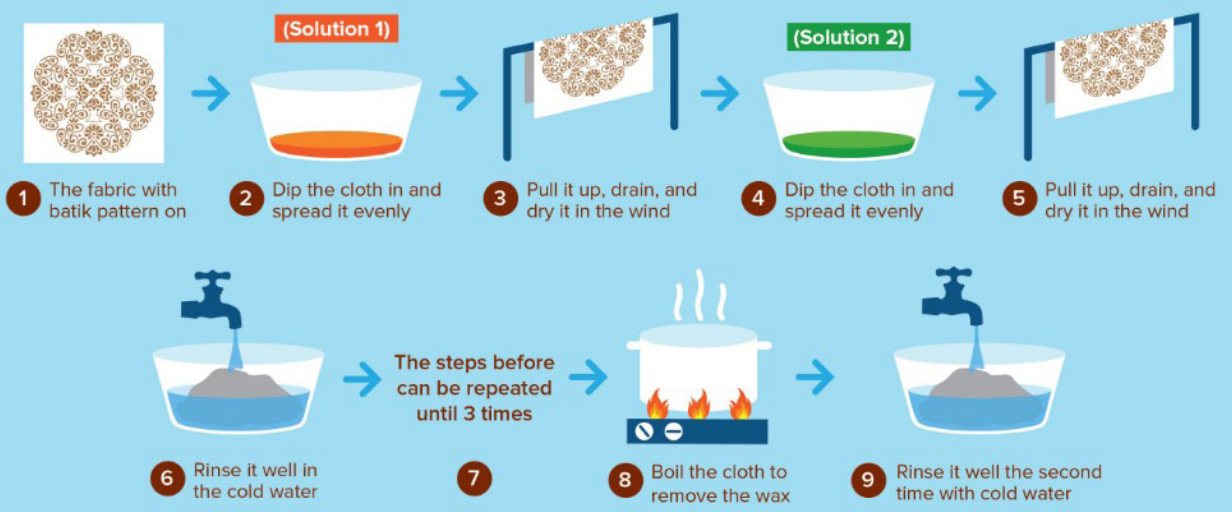

Figure 3. Chart of the stages and steps in coloring. Chart drawn by Wuri Handayani. 
into the concrete one, in which they were implementing the materials and technical procedures into the forms and types of products that fit the purpose of their research. To clarify the embodiment of the work, it can be visualized by manual drawings and computer digitization to produce good working drawing.

c. Experiments, modification of techniques, and forms of decoration to form textures and decorative patterns (Sharifah et al., 2017); (Kasim et al., 2017).

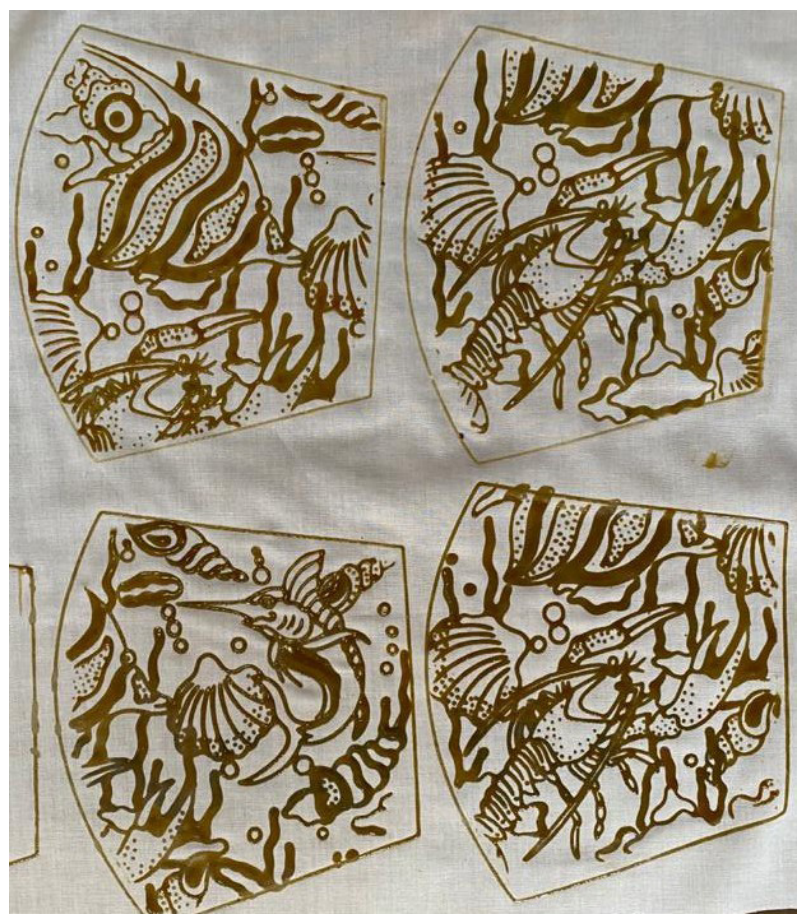

Figure 4. Resist-dyeing process of Batik using hot wax on the cloth.

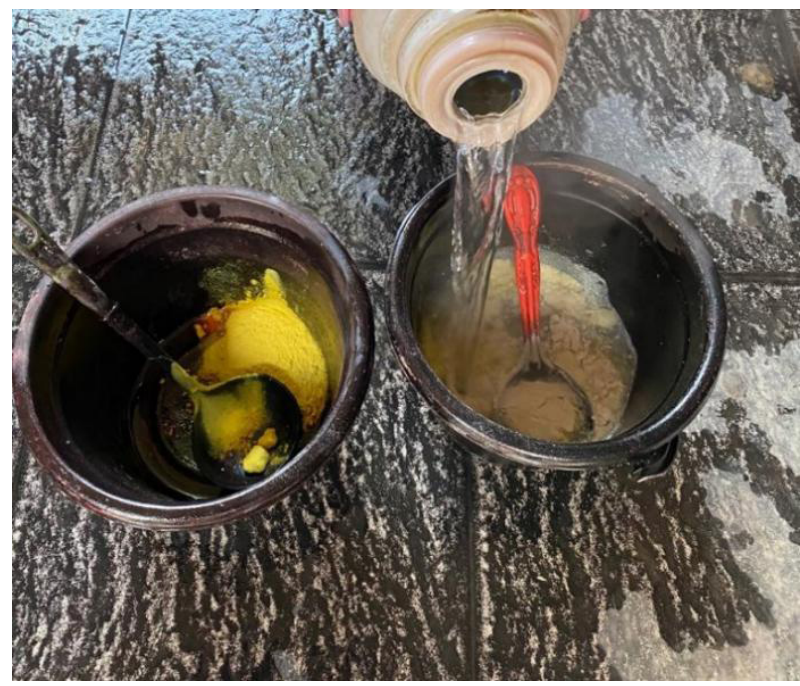

Figure 5. The fabric dye (Nap) paste.

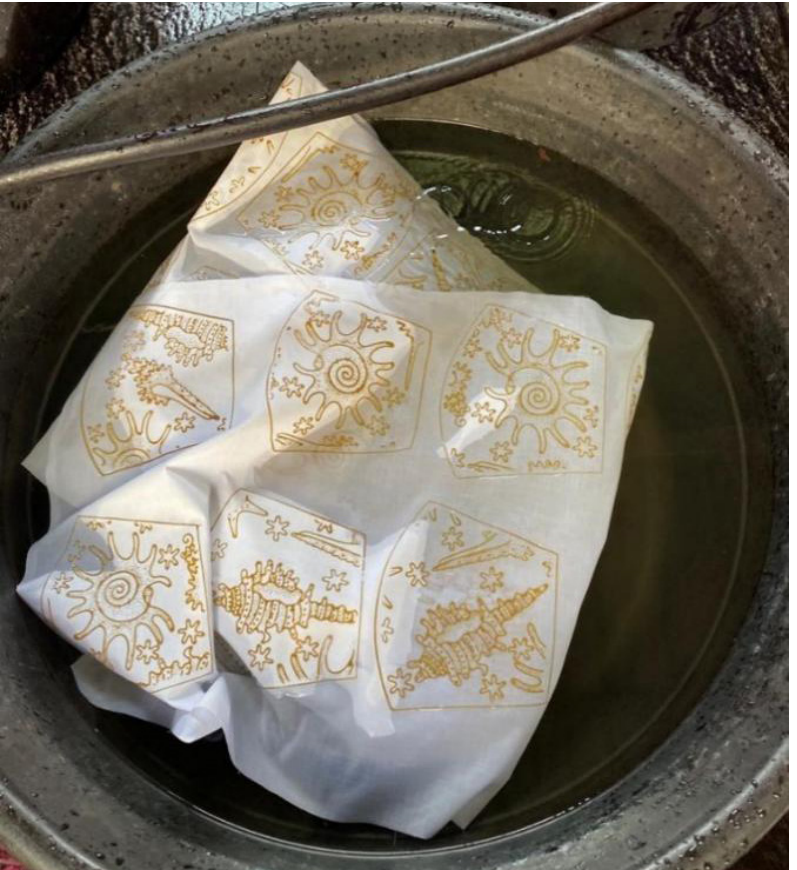

Figure 6. The dyeing of batik cloth in the fabric dye (Naphthol).

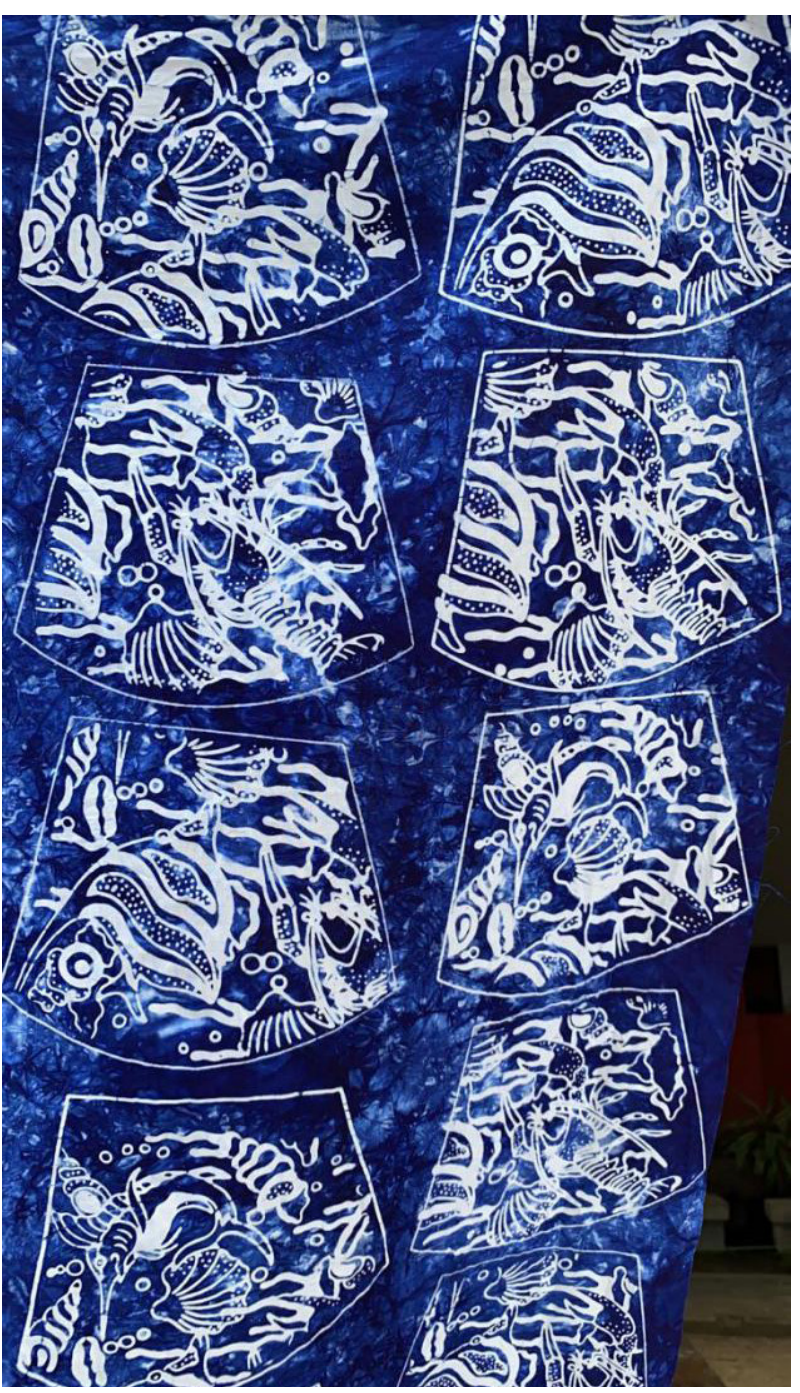

Figure 7. Results of the blue fabric dyeing. 
d. Energy savings in the process of making printed batik (Djunaidi \& Setyaningsih, 2017)

4. Prototype is the next stage, in which the designers/researchers worked on a spatial study process to further the implementation of 3D model (manufacture modeling) and working drawings that ultimately lead to the design decision and the presentation of the final design in the form of prototype or batik mask model. At this stage, it was also necessary to test the feasibility of the batik mask that will be mass produced with various tests, which are a shape test, strength test, comfort test, and artistic
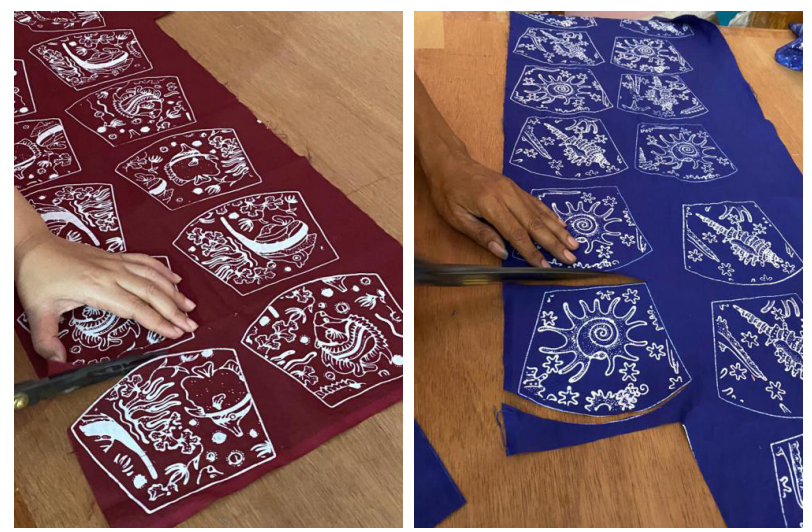

Figure 8. Cutting patterns for the mask.

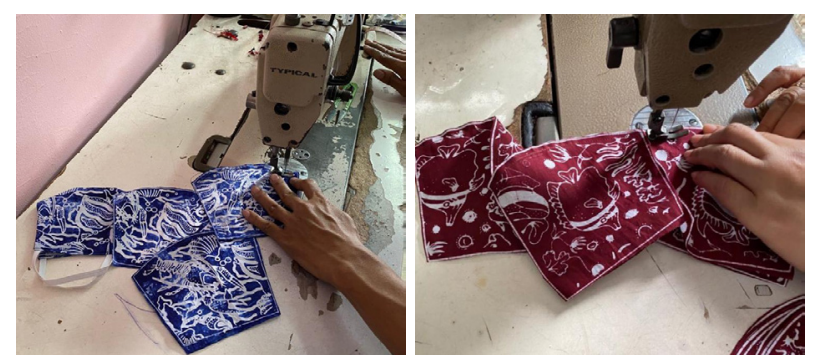

Figure 9. The sewing process of the mask.

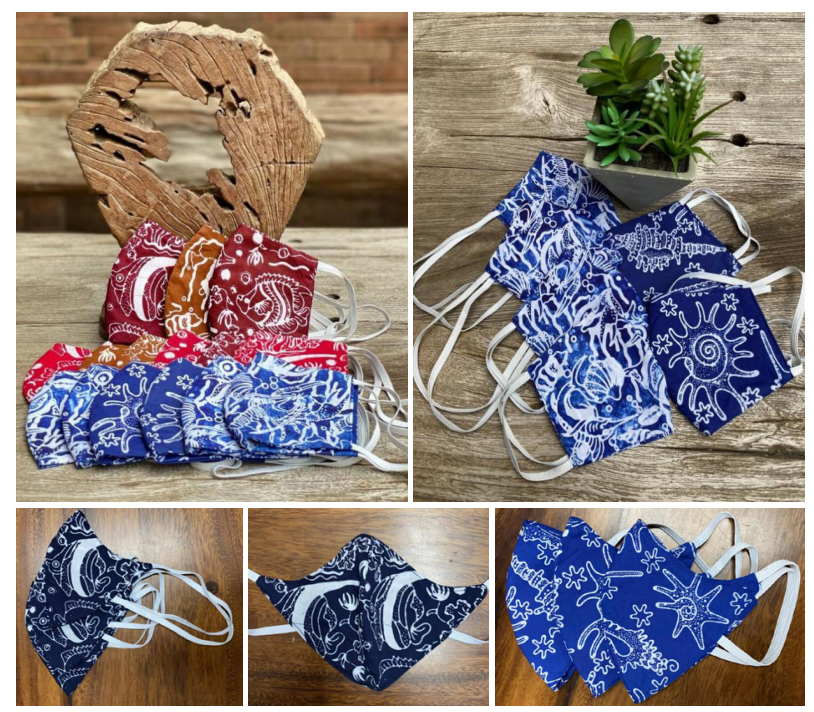

Figure 10. Final products. test, and market test (assessing its appeal to the consumers).

5. Test is the final stage, in which the designers/ researchers presented the creative process step by step from the idea to the prototype that has been done to obtain feedbacks from others, appreciators, consultants, and clients. At this stage, it was expected that the researchers might redefine the focus of the issues that might still exist both in the product and in its users to measure the success rate from the solutions and innovations that had been designed. In other words, this stage was more at the level of achieving the problematic quality of the product related to its efficiency and targeted. Therefore, it can be produced in large quantities with a very minimum failure rate in the following productions.

\section{Conclusion}

The results of applied research of practiceled research in the fields of arts, crafts, and design are not only in one target area of strengthening economic value and practical business. The core of practice-led research in art, craft, and design is creativity. Creativity as the essence and spirit of science, of course, can contribute to someone's intelligence, sensitivity, and sensibility. Creators with sensitivity and sensibility obtain it by learning from phenomena occurring in their lives. Therefore, this becomes an additional value to their intelligence and creativity in creating their works. This actually has more value than merely the practical economic value. The novelty value does not merely mean new in the sense that there has never been anything else like a certain work of art before. However, the novelty value focuses more on: (1) the process of learning to understand oneself from the map of activities and creativity in the field to which they devote their lives to towards other existences that exist in wider maps and (2) the learning process to appreciate similar works that existed before. Therefore, the objectivity of the added values and/or the novelty value will be obviously seen even though it is only has the size similar to that of a watermelon seed. 


\section{Acknowledgment}

The authors would like to thank the Research and Community Service Information System (Simlitabmas) and Institute for Research, and Community Service (LPPM) of Bandung Institute of Indonesian Arts and Culture (ISBI). This article is one of the outputs of the applied research funded by Ministry of Research and Technology/National Research and Innovation Agency of the Republic of Indonesia (Ristekdikti/Ristekbrin) 2019-2021.

\section{References}

Atiqoh, NSari, D. P., \& Sholihah, A. (2020). Hubungan antara pengetahuan masyarakat dengan kepatuhan penggunakan masker sebagai upaya pencegahan penyakit COVID-19 di Ngronggah. INFOKES Journal, 10(1), 52-55. http://ojs.udb.ac.id/index.php/ infokes/article/view/850

Ananda, A. D., \& Susilowati, D. (2019). Pengembangan Usaha Mikro Kecil dan Menengah (UMKM) Berbasis Industri Kreatif di Kota Malang. Jurnal Ilmu Hukumrnal Ilmu Ekonomi.

Dipta, I. W. (2008). Strategi Penguatan Usaha Mikro, Kecil Dan Menengah (UMKM) Melalui Kerjasama Kemitraan Pola CSR. INFOKOP.

Djunaidi, M., \& Setyaningsih, E. (2017). Pemilihan Alternatif Penghematan Energi pada Proses Produksi Batik Cap dengan Menggunakan Metode Mcdm-Promethee. Spektrum Industri, 15(2), 223. https://doi. org/10.12928/si.v15i2.7555

Hanfan, A. (2017). Membangun Keunggulan Produk Ikonik Untuk Meningkatkan Kinerja Pemasaran UMKM. DeReMa Jurnal Manajemen.

Hendriyana, H. (2018). Metodologi Penelitian Penciptaan Karya: Seni Kriya dan Desain Produknon Manufaktur) (B. Sapto (ed.); first). Sunan Ambu Press. http://perpustakaan.isbi. ac.id/?menu=search\&action=simple\&keywo $\mathrm{rd}=$ metodologi+penelitian+penciptakaan $+\mathrm{ka}$ rya+\&coll_type=book
Kasim, A. A., Wardoyo, R., \& Harjoko, A. (2017). Batik classification with artificial neural network based ontexture-shape feature of main ornament. International Journal of Intelligent Systems and Applications, 9(6), 55-65. https:// doi.org/10.5815/ijisa.2017.06.06

Li, Y., Hu, C. J., \& Yao, X. (2009). Innovative batik design with an interactive evolutionary art system. Journal of Computer Science and Technology. https://doi.org/10.1007/s11390009-9293-5

Ngatini, N., Putri, M. M., Ibrahim, M. F., Bariyah, T., \& Mardhiyyah, Y. S. (2020). Pemberdayaan ibu-ibu Desa Manukan Bojonegoro dalam mengembangkan Batik Jonegoroan sebagai rintisan industri kreatif. Riau Journal of Empowerment, 3(1), 17-25. https://doi.org/10.31258/raje.3.1.17-25

Nury Ariani Wulansari, Desti Ranihusna, \& Ida Maftukhah. (2015). Strategi Perencanaan Sdm Untuk Peningkatan Daya Saing Umkm Batik Semarang. Prosiding Seminar Nasional Multi Disiplin Ilmu \& Call for Papers Unisbank (Sendi_U).

Pakpahan, A. K. (2020). Menyelamatkan Penjualan Ritel di Tengah Pandemi Covid-19. Covid-19 Dan Implikasi Bagi Usaha Mikto, Kecil, Dan Menengan, 1(April), 5. https://doi.org/https:// doi.org/10.26593/jihi.v0i0.3870.59-64

Pratiwi, I., \& Kartikasari, I. (2018). Evaluation of work posture for non repetitive job in Kampoeng Batik Laweyan using PATH and OWAS method. AIP Conference Proceedings, 1977. https://doi.org/10.1063/1.5042907

Ramadhan. (2020). Strategi Pemulihan UMKM di Masa New Normal. Asumsi.Co. https://www. asumsi.co/post/strategi-pemulihan-ekonomiumkm-di-masa-new-normal

Ridwan, M., . H., \& Hatuwe, M. (2014). Pembinaan Industri Kecil Dan Menengah Pada Dinas Perindustrian, Perdagangan, Koperasi Dan Umkm Kota Bontang. Jurnal Administrative Reform (JAR).

Sarma, Ma’mun. (2020). "Entrepreneurial Marketing untuk Keberhasilan Pemasan UMKM di masa Pandemi", Virtual Guest Lecturer, Department of Management faculty of 
Economics Management IPB. 11 Mei 2020.

Sharifah, I. S. S., Nurul, A. T. B. S. T., \& Khairusshima, M. K. N. (2017). Thermal Modelling and Analysis of Batik Canting Design. Procedia Engineering, 184, 326-333. https://doi. org/10.1016/j.proeng.2017. 04.102

Sucahyawati, A. H. K. (2019). Dimensi Kreativitas dan Pengembangan Usaha Mikro Kecil dan Menengah ( UMKM ). Jurnal Hummansi.

Sugiyarto, S. (2020). Pemberdayaan Karang Taruna dalam Pencegahan Penyebaran Covid-19 di Desa Wonokerto Kecamatan Wonogiri. Jurnalempathy. Com, 1(1), 35-41. https://doi. org/10.37341/jurnalempathy.v1i1.5

Sunaryo, D. (2020). Pembuatan Masker Kain Sebagai Pencegahan Penularan Virus serta Mengoptimalkan Pendapatan di Masa Pandemi COVID-19 bagi Masyarakat di Desa
Sukaratu. ABDIDAS Community Development Service on Educational and Health Sciences, 1(4), 183-192. https://doi.org/10.31004/ abdidas.v1i4.40

Suroso Putro, T. A., Dinata, R., \& Ramadhan, A. (2019). STUDY OF APPLICATION "BATIK" IN THE INTERIOR OFFICE PARTITION. Journal of Urban Society's Arts. https://doi.org/10.24821/jousa.v6i2.3187

Tri U, D. D. (2013). Pengembangan Usaha Mikro Kecil Dan Menengah (Umkm) Berbasis Ekonomi Kreatif Di Kota Semarang. In Ilmu ekonomi.

Wibowo, Dwi Mukti. (2020). "Stimulus dan Gerak UMKM di Masa Pandemi”, Virtual Guest Lecturer, Department of Management faculty of Economics Management IPB. 11 Mei 2020. 